IRA-International Journal of Management \& Social Sciences

ISSN 2455-2267; Vol.08, Issue 01 (July 2017)

Pg. no. 81-90

Institute of Research Advances

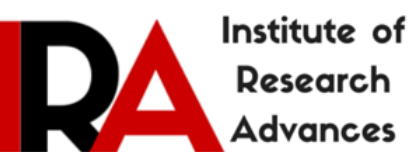

http://research-advances.org/index.php/RAJMSS

\title{
The Relevance of Marketing Mix and Service Quality on Students' Decision-Making Factors Regarding Higher Education and Satisfaction
}

\author{
Bakhtiar Tijjang $^{1}$, Jeni Kamase ${ }^{2}$, Ilham Labbase ${ }^{3}$, Annas Plyriadi ${ }^{4}$ \\ ${ }^{1} \mathrm{PhD}$ Candidate, Postgraduate in the Faculty of Economics, Muslim University of Indonesia, \\ Indonesia. \\ ${ }^{2,3,4}$ Faculty of Economics, Muslim University of Indonesia, Indonesia.
}

Type of Review: Peer Reviewed.

DOI: http://dx.doi.org/10.21013/jmss.v8.n1.p9

\section{How to cite this paper:}

Tijjang, B., Kamase, J., Labbase, I., \& Plyriadi, A. (2017). The Relevance of Marketing Mix and Service Quality on Students' Decision-Making Factors Regarding Higher Education and Satisfaction. IRAInternational Journal of Management \& Social Sciences (ISSN 2455-2267), 8(1), 81-90. doi:http://dx.doi.org/10.21013/jmss.v8.n1.p9

(C) Institute of Research Advances.

\section{$(\mathrm{cc}) \mathrm{BY}-\mathrm{NC}$}

This work is licensed under a Creative Commons Attribution-Non Commercial 4.0 International License subject to proper citation to the publication source of the work.

Disclaimer: The scholarly papers as reviewed and published by the Institute of Research Advances (IRA) are the views and opinions of their respective authors and are not the views or opinions of the IRA. The IRA disclaims of any harm or loss caused due to the published content to any party.

Institute of Research Advances is an institutional publisher member of Publishers Inter Linking Association Inc. (PILA-CrossRef), USA. The institute is an institutional signatory to the Budapest Open Access Initiative, Hungary advocating the open access of scientific and scholarly knowledge. The Institute is a registered content provider under Open Access Initiative Protocol for Metadata Harvesting (OAI-PMH).

The journal is indexed \& included in WorldCat Discovery Service (USA), CrossRef Metadata Search (USA), WorldCat (USA), OCLC (USA), Open J-Gate (India), EZB (Germany) Scilit (Switzerland), Airiti (China), Bielefeld Academic Search Engine (BASE) of Bielefeld University, Germany, PKP Index of Simon Fraser University, Canada. 


\begin{abstract}
This study conducted aims to examine and analyze the relevance of marketing mix and service quality on the students decision-making, the relevance of marketing mix, service quality on student satisfaction and the effect over decisions related on student satisfaction and the relevance of marketing mix and service quality on student satisfaction as a mediating role of students decision-making. Population in this study were all a new students in the study program management, education level of Bachelor degree of the academic year 2015/2016 in Makassar. There are 381 students were used as samples. Data were analyzed using Structural Equation Modelling (SEM) with support Analysis of Moment Structures (AMOS). This study provides findings that the marketing mix and service quality has a significant effect on students decision-making, marketing mix does not directly effect in student satisfaction, services quality and student's decision-making has a significant on student satisfaction. Marketing mix and service quality has a significant effect on student satisfaction as a mediating role of student's decision-making. These findings explain that the marketing mix directly affects decision-making, but has no direct effect on satisfaction; marketing mix can affect satisfaction if supported by the student's decision-making. Service quality affects directly and indirectly on satisfaction as a mediating role of decision-making.
\end{abstract}

Keywords: Marketing mix, service quality, students decision-making, satisfaction

\title{
Introduction
}

The impact of globalization has an impact on the world of higher education and universities in Indonesia, the symptoms are further strengthened by the free movement of science and technology is one important aspect of globalization, especially in the field of higher education. In general, the target market is college students who will partly continue on to college. Graduates High School (SMA) who will continue their education to college would want to be later completed quickly and then easily get a job.

The development of the college to get a professional quality, in accordance with the constitutional mandate as stated in the Law of the Republic of Indonesia No.12 of the year 2012 on Higher Education, Article 51 paragraph (1) that, quality higher education is higher education that produces graduates able to actively develop their potential and to generate knowledge and / or technologies that are useful to society, nation, and state.

In terms of quantity, the number of universities in Makassar surge sharp enough. Until 2015 the number of private universities in Makassar has reached 214 universities consisting of State Universities (PTN) and Private Universities (PTS). This figure increased in comparison from the year 2011 which amounted to only 187 College, an increase of $14 \%$. However, the fate of the College in Indonesia looks very alarming when compared with universities from all over the world. Web metric, the site of the rating of all universities in the world through the university's website, shows that the University of Gajah Mada (UGM) was ranked 9th in rank in Southeast Asia. This was followed by the University of Indonesia (UI) in the rankings to 15th. Universities that are ranked first come from Thailand, Singapore and Malaysia. However, it is ranked Gajah Mada University (UGM) in global scope ranks 381. University of Indonesia (UI) was ranked 508. Mean while the two universities have spawned a lot of professionals in their respective fields.

Universities and colleges in the province of South Sulawesi, such as Hasanuddin Universities (UNHAS) is ranked 45th in Southeast Asia while the scope is global in scope is ranked 1.231.Universitas all of Makassar (UNM) was ranked 318 within the scope of the Southeast Asia while global in scope is at number 6725. The figures above show that the quality of higher education in Indonesia is still too much when compared with other higher education in a global scope. Thus, some improvement is absolutely necessary to continue to be able to catch up with other nations.

The increasingly fierce competition among universities in Indonesia requires the need to improve the services quality, both in terms of academic administration services, services for the provision of adequate 
and services quality has a new admissions. Higher education should not only be seen as a centre of science, research centres, and community service centre, but also a corporate entity producing science, which compete to ensure survival. The phenomenon of competition in service companies, including marketing mix, price, promotion, place and service quality. The college as a non-profit entity, also facing the same thing for it required knowledge and skills as well as, the management of the college (Mandey, 2009: 7).

This marketing approach is done to see how we can meet the needs and desires of consumers by exchanging products and value. Furthermore, fulfilling the needs and desires is what we will formulate into a proper marketing strategy. The marketing strategy is a marketing logic, and based on that, the business unit is expected to achieve its marketing goals. The marketing strategy consists of making decisions about the marketing costs of the company, marketing mix and marketing allocation in relation to the expected environmental conditions and the conditions of perfect competition (Philip Kotler, 2009: 42).

The results of previous studies, suggest that there are seven factors affecting student satisfaction on the three leading Colleges in Bandung. Seventh these factors include: Product or Service of the greatest contribution in the creation of student satisfaction, price has a significant effect on the location, process or service management of physical evidence and human resources hereinafter Location college, then sequentially factor of human resources, physical evidence, then the process, and the promotion has a positive but not significant effect on the student satisfaction (Soedijati et al., 2011: 101).

Today's in Indonesia shows that the capacity of students at State Universities (PTN) is very limited. Then all Private Universities (PTS), particularly in Makassar have the same opportunities to be selected by prospective students who are not accommodated at the State University in continuing his studies. Therefore every College must perform a different specific strategy. The size of the ability to obtain a student depends on the delivery of information about private universities concerned, which is evident from marketing mix strategies are applied. In addition to marketing mix strategy, accreditation status also affects the student's decision in choosing Colleges as a place to study.

Past studies provide evidence that students are satisfied can attract new students through positive word of mouth communication to friends and relatives, and possibly after graduation will be returned to college to study advanced level (Coal \& Lopez, 2015).Other researchers, such as the studies conducted Srinadi \& Nilakusmawati (2008) proved that a reliability factor of the dominant influence in determining the student's satisfaction with the services the faculty as an educational institution. The influence of the quality of service to satisfaction of $18 \%$, the greatest effect is obtained from the variable reliability, followed by the variable responsiveness, and empathy. As for the certainty of variables influence the most low (Ariyanti et al., 2006)

\section{Literature review}

\section{Marketing Mix}

Marketing concept is Achieving organizational objectives and needs depend on determination target market wants and delivery of the coveted satisfaction was more effective compared to competitors (Kotler \& Armstrong, 2008; 12). Services are all activities or benefits that may be offered one party to another in which the activity or benefit that is essentially intangible and does not produce any ownership (Kotler \& Armstrong, 2008; 266). In the execution of manufacturers using a variety of ways to market products and services resulting from it, one way is stated in the marketing mix is a collection of marketing tools tactical restrained combined company to produce the response it wants in the target market (Kotler \& Armstrong, 2008; 62). The views of other experts, said the marketing mix is a combination of four variables or activities that constitute the core of the company's marketing system of product, price, promotion and distribution activity. There are many marketing tools (Stanton, 1996).

The concept of traditional marketing mix consists of; product, price, promotion, place. In marketing services $4 \mathrm{P}$ use inadequate, requiring an expanded marketing mix for services with the addition of nontraditional marketing mix elements, namely people, physical evidence and process, thus becoming the 7P's. The seventh component of the marketing mix of goods that include: price, promotion, product, distribution 
channels, people, process, and physical environment, where the use of a combination of seven of these variables depend on the managers of companies (Johnston \& Marshall, 2008).

Marketing mix has a positive and significant effect on customer satisfaction (Didik \& Ikasari, 2014). Dimensional of marketing mix at prices significantly effect on the purchasing behaviour, while the dimensions of the products, distribution channels and promotion not significant effect on the purchasing behaviour (Pupuani \& Sulistyawati, 2013).

\section{Service quality}

Service quality is a conception that is abstract and elusive, as the service quality has the characteristics of intangibles, variability, non-durable (perishability), as well as production and consumption of services occurring simultaneously (inseparability) (Parasuraman et al., 1994). However, it does not mean the quality of service cannot be measured. Perception of the quality of service is defined as a thorough assessment of the advantages of a service, while expectations for the quality of service is defined as customer confidence before trying or buying a product, which is used as a reference or standard in assessing the product (Tjiptono, 2000: 61). The definition of services quality is focused on meeting customer needs and desires, as well as its delivery accuracy to compensate customers' expectations. A positive perception of quality is obtained when the quality experienced quality meet customer expectations (expected quality). When the customer expectations are not realistic, then the perception of the total perceived quality will be low.

Empirical research is based on exploration works produce SERVQUAL, the scale items are used to measure service quality along five dimensions: reliability, responsiveness, assurance, empathy, and tangibles (Parasuraman et al, 1994), the five key dimensions of SERVQUAL namely: (1) reliability, the ability to provide the promised service with immediate, accurate, and satisfactory, (2). Responsiveness, which is the desire of the staff to help customers and provide service with a response, (3) assurance, including knowledge, skills, courtesy, and trustworthiness owned by its staff, free from danger, risk, or hesitations, (4) Empathy, including ease in the relationship, good communication, personal attention, and understand the needs of customers, and (5) tangibles, including physical facilities, equipment, employees, and means of communication.

Service quality model of the popular to made reference in marketing research is SERVQUAL (service quality) developed by Parasuraman et al. (1994) This model is asserted when the performance on attributed performance increased greater than the expectation on the attribute in question, the services quality will also increase. The findings of previous researchers, provide evidence that the service quality positive and significant effect on customer satisfaction (Said, 2002; Dwi Aryani \& Febrina Rosinta 2010; Sebastian Daimon, 2011; Richard Marvind 2011; Rinala et al., 2013).

Purchase decision (student's decision-making)

Consumer behaviour, explaining that besides purchasing decisions are influenced by consumer characteristics, can be influenced by marketing mix that includes product, price, distribution, and promotion. These variables affect each other over the purchase decision process resulting in a purchase decision based on product choice, brand choice, the dealer choice, the choice of the time of purchase, the purchase amount (Kotler, 2009: 88). Once known motive, behaviour and purchasing habits, every force and marketing leaders must also understand about the processes and purchasing decisions (Assauri, 2010: 56).

The purchase decision-making process varies greatly. Some are simple and some are complex. The decision making process includes, extended decision-making, limited decision-making, and habitual decision-making (Peter \& Olson, 2013: 165). Comprehensive decision-making process occurs for special interests for consumers or for decisions that require a high level of engagement. Limited decision-making process occurs when consumers recognize the problem, and then evaluate several alternative products or brands is based on knowledge without trying (or just do a little effort) seek new information about the product or the brand. Decision-making model is all affection and cognitive aspects involved in decisionmaking, including knowledge, meaning, and the trust that is activated from the memory and attention and understanding of the process involved in the interpretation of new information in the environment (Peter \& Olson, 2013: 162). 
Past studies prove that the product, price, place, promotion significantly influence the purchase decision. Price is a dominant variable influencing purchasing decisions (Widarko \& Sunaryo, 2015; Pratiwi \& Sudiksa, 2013). SERVQUAL significantly associated with intention and tourists in the future (Canny 2013). Only the dimensions of the product and the price associated with the decision making of customers on travel agents, while the marketing mix is not able to give effect to the decisions of customers (Satit et al., 2012), There is a significant effect of the marketing mix on satisfaction and purchase decisions (Hermawan, 2016),

Satisfaction (Students satisfaction)

Satisfaction is a comparison of perceptions of the services received by expectations before using the services (Jasfar, 2005; 14). Customer satisfaction is an emotional response to the experience of consuming a product for services (Tjiptono, 2000; 109). Satisfaction is a response to people who are subjective attitude towards a particular object after comparing between expectations and reality. Attitudes are evaluative statements, whether favourable or unfavourable, about objects, people, or events. Feelings favour or partiality (favourable) and favourable evaluative statements can also be referred to the satisfaction of the individual against a particular object (Robbins, 2003; 57).

Attitude consists of three (3) components: cognitive, psychomotor, and affective; attitude is influenced by several factors: 1) a personal experience; 2) the influence of others that are considered important; 3) cultural influences; 4) the mass media; 5) educational institutions and religious institutions; 6) the impact of emotional factors.

Individual attitude shaped by its cognitive process and manifested in the behaviour and attitudes towards a particular object is also affected by various factors, where the emotional factor plays a fairly important. So it can be said that the concept of satisfaction itself as a concept that is relative (Robbins, 2003: 59).

The findings of previous studies, proving that satisfaction significantly influence the purchasing behaviour (Pupuani \& Sulistyawati, 2013). SERVQUAL has a positive and significantly effect on tourist satisfaction (Canny, 2013). All aspects of customer expectations, higher than their perceptions of the Bank's operations, and in fact the low quality of services offered.

In addition, these results show that customer satisfaction plays a role as a mediator in analyzing the impact of service quality on service loyalty (Mosahab et al., 2010). There is a positive and significant effect on the satisfaction of the marketing mix, as a mediating role of purchase decision (Hermawan, 2015).

\section{Methods}

This study uses causal research also known as explanatory research is conducted in order to identify the extent and nature of cause-and-effect relationships. Causal research can be conducted in order to assess the impacts of specific changes on existing norms, various processes etc. Causal studies focus on an analysis of a situation or a specific problem to explain the patterns of relationships between variables (marketing mix, service quality, decision making and student satisfaction at Colleges).

The population in this study were all students who take the classes at undergraduate management level courses are listed in the private universities Makassar in 2015/2016 academic year, the number of 8,144 students spread over 29 Colleges in Makassar (Kopertis Region IX). Then, using formulations Slovin, then obtained a total sample of 381 students. The data were analyzed using Structural Equation Modelling (SEM) through support analysis of moment structures (AMOS) Ver. 20 


\section{Results and discussion}

Table 1. Goodness of fit indices overall model

\begin{tabular}{|l|c|c|c|}
\hline \multicolumn{1}{|c|}{ Goodness of fit index } & Cut-off Value & Results Model * & Description \\
\hline Chi-square & small expected & $180.550<180.676$ & Good \\
\hline Probability & $\geq 0.05$ & 0,051 & Good \\
\hline CMIN / DF & $\leq 2,00$ & 1,196 & Good \\
\hline RMSEA & $\leq 0,08$ & 0,023 & Good \\
\hline GFI & $\geq 0,90$ & 0,957 & Good \\
\hline AGFI & $\geq 0,90$ & 0,935 & Good \\
\hline TLI & $\geq 0.94$ & 0,994 & Good \\
\hline CFI & $\geq 0.94$ & 0,996 & Good \\
\hline
\end{tabular}

The results of goodness of fit indices models indicate that the eight criteria for goodness of fit indices it meets the criteria, so that the overall model can be said to have been in accordance with the data and can be analyzed further.

Table 2. Hypothesis testing

\begin{tabular}{|c|c|c|c|c|c|c|}
\hline \multirow{2}{*}{ Exogenous } & Endogenous & Standardize & $\begin{array}{c}\text { Critical } \\
\text { ratio } \\
\text { (CR) }\end{array}$ & p-value & Description \\
\cline { 3 - 7 } & Marketing Mix & $\begin{array}{c}\text { Students } \\
\text { decision-making }\end{array}$ & 0,439 & 4,371 & 0,000 & Significant \\
\hline Service quality & $\begin{array}{c}\text { Students } \\
\text { decision-making }\end{array}$ & 0,444 & 4,456 & 0,000 & Significant \\
\hline Marketing Mix & $\begin{array}{c}\text { Students } \\
\text { satisfaction }\end{array}$ & 0,013 & 0,157 & 0,875 & insignificant \\
\hline Service quality & $\begin{array}{c}\text { Students } \\
\text { satisfaction }\end{array}$ & 0,272 & 3,352 & 0,000 & \multicolumn{2}{|c|}{ Significant } \\
\hline Students decision- & $\begin{array}{c}\text { Students } \\
\text { matisfaction }\end{array}$ & 0,670 & 8,506 & 0,000 & \multicolumn{2}{|c|}{ Significant } \\
\hline Exogenous & Intervening & Endogenous & Standardized & P-Value & Description \\
\hline Marketing Mix & $\begin{array}{c}\text { Students decision- } \\
\text { making }\end{array}$ & $\begin{array}{c}\text { Students } \\
\text { satisfaction }\end{array}$ & 0,294 & 0,000 & Significant \\
\hline Service quality & $\begin{array}{c}\text { Students decision- } \\
\text { making }\end{array}$ & $\begin{array}{c}\text { Students } \\
\text { satisfaction }\end{array}$ & \multicolumn{2}{|c|}{0,297} & 0,000 & Significant \\
\hline
\end{tabular}

The test results indicate that there is a path coefficients contained seven lines in the model, one of which showed positive results and insignificant, while in other parts of the overall show positive results and significant,

\section{Effect of marketing mix on student's decision-making}

Marketing mix has a positive and significant effect on students decision-making with a p-value $=0,000<$ 0,05 with a regression coefficient value of 0.439 , the regression coefficient indicates that the higher the level of accuracy of the marketing mix results in a high quality of decision making in choosing a college student. Marketing mix is positive and significant effect on student's decision-making. These findings support previous research, that the marketing mix significantly influences purchasing decisions (Pratiwi \& Sudiksa, 2013). That the marketing mix is a variable that is very precise in influencing consumer purchasing decisions (Schifman \& Kanuk, 2007).

The marketing mix can make a positive contribution on students decision-making in selecting a private university, that a good marketing mix strategy will affect the result to be achieved; many consumers are interested in buying the services offered. In other words, with the products offered interesting, appropriate 
price, exciting promotions and a good distribution. Then consumers would be interested in choosing the product. Facts on the ground indicate that in general students in making decisions on continuing the study due to the level of accreditation obtained from Indonesian private College Board of accreditation that measures the quality of educational institutions (BAN-PT).

\section{Effect of services quality on student's decision-making}

Service quality is positive and significant effect on students decision-making with a p-value $=0,000<0,05$ and regression coefficient value of 0.444 , the regression coefficients showed that the higher the services quality provided to students the impact on improving the quality of decision making of students to choose private university. Service quality is positive and significant effect on student decision-making. These findings indicate that the higher the perceived service quality, it resulted in high ability students in making decisions to choose a college.

These results support the findings of previous investigators that the service quality significantly affects on students decision-making. Service quality is a benchmark in determining purchase decisions whether or not a user of the service, because it is through of service quality will be able to assess the performance and feel satisfied or whether they are with the services provided by the service providers (Dimas, 2014).

Factors guarantee a significant reason the effect on service quality on student's decision-making as evidenced by the high level of confidence in the ability of faculty students in the process of education and teaching. This study supports the statement of the expert, that the quality of service is a thorough assessment of the benefits of a service. When the assessment generated a positive assessment, the quality of these services will have an impact on the purchase decision (Nasution, 2004: 50).

\section{Effect of marketing mix on student's satisfaction}

The marketing mix has a positive and insignificant effect on student satisfaction as evidenced by the pvalue $=0,875>0,05$ with the regression coefficient value of 0,013 . The regression coefficient value indicates that the marketing mix used private universities cannot increase student satisfaction directly. The results of this study refute the findings of previous investigators, that the marketing mix has a positive and significant effect on student satisfaction (Gultom et al., 2014).

Facts on the ground indicate that in general students are not satisfied with the selection of the Private colleges that have been chosen, because it was what was communicated at the time of promotional activities do not correspond to the expectations of students, so that students expect continuous improvements related to the marketing mix, particularly the fact that expected at the time of campus marketing promotion.

\section{Effect of service quality on student's satisfaction}

Service quality is positive and significant effect on student satisfaction, evidenced by the p-value $=0,000<$ 0,05 with the regression coefficient value of 0,272 , the value of the regression coefficient value showed that the higher level of service quality which received by the students so the higher level of student satisfaction. These results support previous studies that the services quality of academic significantly affects on student satisfaction (Rinala et al., 2013).

Build student satisfaction is at the core of achieving the long-term profitability. Satisfaction is a difference between expectations and performance. When expectations are high, while his work is mediocre, satisfaction will not be achieved (very likely consumers will be disappointed). Conversely, if the performance more than expected has increasing satisfaction (Zeithaml \& Bitner, 1996). Physical evidence in the world of higher education is the appearance of physical facilities, equipment, personnel and equipment / communication materials that support the learning process / college. Physical evidence in the world of higher education includes the following: physical facilities where lectures, facility or infrastructure, lecture equipment, employees, marketing and lecturer, communication tools and communication materials. Facts on the ground indicate that the student will be satisfied when you receive a high quality of services, in terms of the services to be supported by the information in the form of academic and service employees who master the job and served well. 


\section{Effect of student's decision-making on student satisfaction}

Students decision-making is positive and significant effect on student satisfaction with p-value $=0,000<$ 0,05 with the regression coefficient value of 0,670 , the regression coefficient value showed that the higher quality level of decision making in which students in selecting a private university, resulting in the level of satisfaction students will increase.

These findings support previous research that the purchasing decisions significantly affect on satisfaction (Hermawan, 2016). Facts on the ground indicate that the student will be satisfied taking undergraduate level (undergraduate), when doing some evaluation and selection of alternative choices in determining college.

\section{Effect of marketing mix on student satisfaction: as a mediating role of student's decision-making} Marketing mix effect on student satisfaction; as a mediating role of student's decision-making with a pvalue $=0,000<0,05$ and the regression coefficient value of 0.294 , the regression coefficient value indicates that the better of marketing mix using the private universities in higher is perceived students satisfaction and due to the support of the higher quality of student's decision-making in choosing a college student. The results support previous studies, that there is a positive and significant impact on the satisfaction of the marketing mix through the purchase decision (Hermawan, 2016).

\section{Effect of service quality on student satisfaction: as a mediating role of student's decision-making}

Service quality affect on the students satisfaction as a mediating role of student's decision-making with a pvalue $=0.000<0.05$ and the regression coefficient value of 0,297 , the results make it clear that a high service quality in higher satisfaction felt by students and due to the support of the higher quality of student's decision-making in choosing a college

\section{Conclusion}

The higher level of accuracy of the marketing mix results in a high quality of decision making in choosing a college student. The higher level of service quality they provide to students the impact on improving the quality of student's decision-making dents to choose the marketing mix used private universities cannot increase student satisfaction. The higher level of service quality is received by students of the higher levels of student satisfaction. The higher the quality of student's decision-making in which students in selecting a private university, resulting in the level of student satisfaction will increase. The better the marketing mix used private colleges resulted in higher satisfaction felt by students and due to the support of the higher quality level of decision making in choosing a college student.

High service quality resulting in higher satisfaction felt by students and due to the support of the higher quality of student's decision-making in choosing a university. It takes leaders ability of private universities, especially the status of accreditation, qualification of lecturers, and information Systems College to be upgraded. Media Information should be of particular concern leaders of private universities, so that students can access information from the campus, including utilizing old students who have received the learning and teaching process and already feel the satisfaction of the college. Service quality should be improved, so that students can benefit, and eventually become a very good source of information on prospective students.

\section{References}

1. Ariyanti, Maya, Tendi Haruman, Iwan Ridwansyah \& Stevanus Adree. (2006). Effect of Service Quality on Satisfaction of University Widyatama Students. Journal of Business, Management and Economics, 7 (3). 873-887.

2. Assauri, Sofjan. (2010). Marketing Management: Basics, Concepts \& Strategies. Jakarta: Raja Grafindo

3. Batubara, A. W., \& Lubis, A. N. (2015). Influence of Service Quality to Satisfaction and Word of Mouth Student Diploma Program III Tax Administration Fisip USU. Journal of Scientific Management \& Business, 14 (2). 
4. Canny, I. U. (2013). An empirical investigation of service quality, tourist satisfaction and future behavioral intentions among domestic local tourist at Borobudur Temple. International Journal of Trade, Economics and Finance, 4(2), 86.

5. Didik, P. \& Hertiana Ikasari. (2014). The Influence of Marketing Mix And Quality Of Service To Consumer Satisfaction At Gading Asri Cottage \& Resto. Thesis, Faculty of Economics \& Business.

6. Dimas, A. N. (2014). The Influence of Marketing and Service Mix On Purchase Decision (Study On Blue Panzer Distortion Semarang City). Thesis, Faculty of Economics \& Business.

7. Dwi Aryani \& Febrina Rosinta. (2010). Business \& Bureaucracy. Journal of Administration and Organization Sciences, 114-126.

8. Gultom, D. K., Ginting, P., \& Sembiring, B.K. (2014). Influence of Service Marketing Mix And Quality Of Service To Student Satisfaction Management Studies Program Faculty of Economics University of Muhammadiyah Sumatera Utara. Journal Scientific Management \& Business, 14 (01).

9. Hermawan, H. (2016). Effect Analysis of Marketing Mix of Consumer Decision, Satisfaction and Loyalty in Purchasing Ceria Bread in Jember. Journal of Management and Business Indonesia, 1 (2).

10. Jasfar, Farida. (2005). Integrated Approach Management Services. Ghalia Indonesia, Bogor.

11. Johnston, Mark W., \& Greg W. Marshall. (2008), Churchill / Ford / Walker's Sales Force Management, 9th ed., Boston: McGraw Hill Irwin

12. Kotler, Philip and Gary Armstrong, (2008). Principles of Marketing. Volume 1. The twelfth edition. Erland. Jakarta

13. Kotler, Philip, \& Kevin Lane Keller. (2009). Marketing Management Volume 2, edition. Third edition of Thirteen, Translation of Bob Sabran, MM. Jakarta: Erlangga Publisher

14. Kotler, Philip. (2009). Marketing Management Jilid 1. Jakarta: PT. Index of Gramedia Group.

15. Mandey, Silvia L. (2009). Effect of Lifestyle Factor on Consumer Purchase Decision, Vol 6 (1) 2009: 92-100.

16. Mosahab, R., Mahamad, O., \& Ramayah, T. (2010). Service quality, customer satisfaction and loyalty: A test of mediation. International business research, 3 (4), 72.

17. Nasution. (2004). Integrated Services Management. Bogor Selatan: Ghalia Indonesia.

18. Parasuraman, A., Zeithaml, V. A., \& Berry, L. L. (1994). Reassessment of expectations as a standard in measuring service quality: implications for further research. The Journal of Marketing, 111-124.

19. Paul, Peter. \& Jerry C. Olson (2013). Consumer Behavior and Strategy. Marketing. Jakarata: Salemba Empat.

20. Pratiwi, P. A. O. A., \& Sudiksa, I. B. (2013). Effect of Marketing Mix Against Consumer Decision in Purchasing of Toyota Avanza Car at PT. Agung Automall Denpasar. E-Journal of Management of Udayana University, 2 (9).

21. Pupuani, N. W., \& Sulistyawati, E. (2013). The Influence of Marketing Mix Against Consumer Satisfaction and Buying Behavior (Case Study on Pepsodent Brand Toothpaste Products in Denpasar City). E-Journal of Management of Udayana University, 2 (6).

22. Republic of Indonesia. (2012). Law of the Republic of Indonesia Number 12 Year 2012 on Higher Education (Supplement to the State Gazette of the Republic of Indonesia of 2012 Number 158, Supplement to the State Gazette of the Republic of Indonesia Number 5336).

23. Richard Marvind, (2011). The Service orientation, Service quality and Price affects Customer satisfaction and Loyalty Australia Airplane.

24. Rinala, I. N., Yudana, I. M., \& Natajaya, I. N. (2013). The effect of Academic Service Quality on Student Satisfaction and Loyalty At Nusa Dua Tourism High School Bali. Journal of Educational Administration, 4 (1).

25. Robbins, Stephen P. (2003). Organizational behavior. Jakarta: PT. GRAMEDIA Group Index

26. Said, Syahnur. (2002). Strategic Factors Affecting Service Quality and Performance of State Universities And Private In Indonesia. Unpublished dissertation, Postgraduate Program of Airlangga University, Surabaya

27. Satit, R. P., Tat, H. H., Rasli, A., Chin, T. A., \& Sukati, I. (2012). The relationship between marketing mix and customer decision-making over travel agents: An empirical study. International Journal of Academic Research in Business and Social Sciences, 2 (6), 522.

28. Schiffman \& Kanuk. (2007). Consumer behavior. Second Edition. Jakarta: PT. Index.

29. Sebastian Daimon, (2011). Analysis of Price, Service quality and Service orientation toward Customer Satisfaction to Increasing the Customer loyalty in Florida Port Company. 
30. Soedijati, Elisabeth Koes \& Sri Astuti Pratminingsih. (2011). The Impacts of Marketing Mix on Students Choice of University Study Case of Private University in Bandung, Indonesia ". 2nd International Conference on Business and Economic Research (2nd ICBER 2011) Proceeding. Bandung: Widyatama University

31. Srinadi, I. G. A. M., \& Nilakusmawati, D. P. E. (2008). Factors Determining Student Satisfaction Of Service Faculty As Education Institution (Case Study in FMIPA, Udayana University). Jurnal Cakrawala Pendidikan, 3 (3).

32. Stanton, Willian, J. (1996). Marketing Principles. Seventh edition. Y. Lagarto. Jakarta: Erlangga.

33. Tjiptono, Fandy. (2000). Management and Contemporary Marketing Perspective, First Edition, First Printing, Andi Offset Publisher, Yogyakarta

34. Widarko, A., \& Sunaryo, H. (2015). The influence of marketing mix to consumer decision in purchasing Daihatsu Xenia car product at PT. Astra Daihatsu Malang. JEMA, 12 (01).

35. Zeithaml, V. A., \& Bitner, M. J. (1996). Service marketing. New York. 